\title{
Our Experience in Plexus Brachialis Block Using Ultrasonography and Nerve Stimulator
}

\author{
Üst Ekstremite Cerrahisinde Uyguladığımı Brakiyal Pleksus Bloğunda \\ Ultrasonografi ve Sinir Stimülatörü Deneyimlerimiz
}

\author{
- Cem Kaçar, • Ebru Tarıkçı Kılıç* • Hakan Akelma, • Ayhan Kaydu**, • Yakup Aksoy***, \\ (๑) Ömer Fatih Şahin***, ๑ Osman Uzundere, ๑ Erhan Gökçek**
}

University of Health Sciences, Gazi Yaşargil Training and Research Hospital, Clinic of Anesthesiology and Reanimation, Diyarbakır, Turkey *University of Health Sciences, Ümraniye Training and Research Hospital, Clinic of Anesthesiology and Reanimation, Istanbul, Turkey

**Diyarbakır Selahaddin Eyyubi State Hospital, Clinic of Anesthesiology and Reanimation, Diyarbakır, Turkey

***Diyarbakır Bismil State Hospital, Clinic of Anesthesiology and Reanimation, Diyarbakır, Turkey

\section{Abstract}

Aim: To compare our experiences of the brachial plexus block (BPB) using nerve stimulator (NS) and ultrasonography (US) for upper limb surgery.

Methods: This retrospective study was designed in 186 American Society of Anesthesiologists I-II-III patients undergoing upper extremity surgery under BPB (supraclavicular, interscalene and infraclavicular block) by US guidance and NS. The patients were divided into two groups as US group ( $n=118)$ and NS group $(n=68)$. Data on demographical characteristics, premedication, position, regional block approach, number of stimulator needles, dose of local anesthetics, and success rate were recorded.

Results: Demographic data were similar and no statistically difference was recorded between the groups in nerve block method (interscalene, supraclavicular, infraclavicular) (p>0.05). $20 \mathrm{~mL} 0.5 \%$ bupivacaine $+10 \mathrm{~mL} 2 \%$ lidocaine were administered. Blocks were performed with a sedation regimen (1-3 mg midazolam). There was a significant difference in success rates between US (94.1\%) and NS groups $(80.9 \%)(p<0.005)$. Horner's syndrome was observed in three patients in NS group (4.4\%), and four patients in US group (4.2). In addition, hematoma, local anesthetic toxicity and pneumothorax were observed in 3.1 and one patients, respectively, in NS group.

Conclusion: Ultrasonographic guidance improves the success of regional anesthesia and causes less complication compared to block using NS.

Keywords: Ultrasonography, upper extremity block, regional anesthesia, nerve stimulator
Amaç: Üst ekstremite cerrahilerinde sinir stimülatörü (SS) veya ultrasonografi (USG) kullanımıyla gerçekleştirdiğimiz brakiyal pleksus bloğu (BPB) deneyimlerimizi sunmayı amaçladık.

Yöntemler: Amerikan Anestezistler Derneği I-II-III, 18-75 yaş BPB (interskalen, supraklavikuler ve infraklavikuler blok yöntemlerinden biri) uygulanarak üst ekstremite cerrahisi geçiren 186 ortopedi hastasının kayıtları retrospektif olarak tarandı. Altmış sekiz hastada SS, 118 hastada USG yardımıyla BPB yapıldı. Gruplar SS ve USG olarak iki gruba ayrıldı. Demografik veriler premedikasyon, pozisyon, blok yaklaşımı, stimülasyon iğnesinin boyutu, lokal anestezik türü, doz, volümü, blok başarısı, komplikasyonlar kaydedildi.

Bulgular: Demografik veriler benzerdi. Blok yöntemi (interskalen, supraklavikuler ve infraklavikuler yöntemlerinden biri) dağılımında istatistiksel anlamlı fark bulunmadı $(p>0,05)$. Lokal anestezik (LA) olarak BPB uygulanan hastalara $20 \mathrm{~mL} \% 0,5^{\prime}$ lik bupivakain $+10 \mathrm{~mL}$ \%2'lik lidokain anestezikten $30 \mathrm{~mL}$ uygulandığı görüldü. Başarı oranı Grup USG'de $(\% 94,1)$ Grup SS'ye $(80,9)$ göre istatistiksel olarak anlamlı derecede artmış bulundu $(p<0,05)$. Grup SS'de üç $(\% 4,4)$, grup USG'de ise beş hastada $(\% 4,2)$ Horner sendromu görüldü. Grup SS'de üç hematom, bir LA toksitesi ve bir hastada pnömotoraks gelişirken grup USG'de başka komplikasyon gözlenmedi. Premedikasyonda 1-3 mg midazolam i.v. yapıldı.

Sonuç: USG klavuzluğuyla BPB, SS klavuzluğuyla yapılana göre blok başarısını arttırmakta, daha az komplikasyona neden olmaktadır.

Anahtar Sözcükler: Ultrasonografi, periferik sinir blokajı, brakiyal pleksus blok, sinir stimülatörü
Address for Correspondence/Yazışma Adresi: Ebru Tarıkçı Kılıç

University of Health Sciences, Ümraniye Training and Research Hospital, Clinic of Anesthesiology and Reanimation, İstanbul, Turkey

Phone: +90 5063306640 E-mail: ebru.tarkc@yahoo.com ORCID ID: orcid.org/ 0000-0002-5377-1090 Received/Geliş Tarihi: 12 August 2017 Accepted/Kabul Tarihi: 01 October 2017
Copyright 2018 by The Medical Bulletin of University of Health Sciences Haseki Training and Research Hospital
The Medical Bulletin of Haseki published by Galenos Yayinevi.

๑Telif Hakkı 2018 Sağlık Bilimleri Üniversitesi Haseki Eğitim ve Araştırma Hastanesi Haseki Tıp Bülteni, Galenos Yayınevi tarafindan basılmıştır. 


\section{Introduction}

Regional anesthesia which is a cost-effective method is frequently used in orthopedic surgeries. It is an effective and safe method of providing analgesia in high-risk situations $(1,2)$. Brachialis plexus block (BPB) is a selective regional anesthetic technique which also minimizes complications such as hypotension and bradycardia (3). The most frequently used blocks are axillary, infraclavicular, supraclavicular, and interscalene. It blocks the ulnar, median and radial nerves (4). This procedure can be done using a nerve stimulator (NS) or with the guidance of ultrasound (US). The technique using a NS is called blind technique based on the distance from the needle to the nerve by using the muscle twitches $(5,6)$. In recent years with the usage of US, the techniques used for regional anesthesia have changed. US-guided block offers advantages compared to traditional techniques and is becoming the common technique. It has been shown to reduce the local anesthetic volume and also the incidence of complications by visualization of the plexus brachialis and the neighboring anatomic structures (7-10). When compared to peripheral nerve stimulation technique, US guidance is more effective, with less pain during awake procedures and reduces the rate of vascular puncture. The rare complications of BPB due to the local anesthetics include nerve injuries, hematoma, infection, and systemic toxicity (4).

In our study, we aimed to evaluate the effectiveness of BPB using a NS and US in 186 American Society of Anesthesiologists (ASA) I-II-III patients aged 18-75 years scheduled for upper extremity surgery in Diyarbakır Gazi Yaşargil Training and Research Hospital from January 2014 to June 302016.

\section{Methods}

A total of 186 ASA I-II-III patients aged 18-75 years who underwent upper extremity surgeries under brachial plexus block anesthesia were enrolled in this retrospective study. After obtaining approval from the ethics committee (12-06-2017/54) of Gazi Yaşargil Training and Research Hospital and written informed consent from all patients, 186 patients undergoing surgeries of the distal arm, forearm or hand, were selected for the study. The demographic data, approaches of the block, position, local anesthetic volume and dosage, success of the procedure, premedication, and complications were recorded. The patients were divided into two groups: US group $(n=118)$ and NS group ( $n=68)$. In group NS, a NS (Braun Stiumplex HNS11, Melsungen, Germany) was used. In group US, all blocks were performed by experienced anaesthesiologists. A linear 38 probe $(10 \mathrm{MHz}$ ) (Mindray UMT-200, SHENZHEN,
P.R.C.) was used for conducting the block. 50-100 mm stimulator needle were used in both groups.

\section{Statistical Analysis}

The data were analyzed using the SPSS (version 19) software. The parametric data were analyzed using Student's t-test and the nonparametric data were analyzed using the chi-square test. A p value of less than 0.05 was considered statistically significant.

\section{Results}

BPB was performed in 186 patients. One hundred eighteen were performed using US guidance and 68 with a NS. In the operation theatre, the patients were monitored with pulse oximetry, non-invasive blood pressure, and electrocardiogram. After establishing an intravenous access, the patients received i.v midazolam (3 $\mathrm{mg}$ ). No other sedation was given until evaluation of the block was completed. During the block period, the supine position was preferred.

Demographic characteristics of the patients were similar between the groups (Table 1). There was no statistically significant difference in gender, age, height, weight and the ASA Physical Status Classification System score between the groups $(p>0.05)$ (Table 1$)$. The technique of BPB is shown in Table 2. There was no statistically significant difference in the approaches of the block and the needle length used ( $p>0.05)$. For all blocks, $0.5 \%$ bupivacaine $20 \mathrm{~mL}$ and $2 \%$ lidocaine $10 \mathrm{~mL}$, totally $30 \mathrm{~mL}$ were administered. In case of block failure, general anaesthesia was performed and recorded. The success rate in US and NS groups was $94.1 \%$ and $80.9 \%$, respectively $(p<0.05)$ (Table 3$)$.

\begin{tabular}{|c|c|c|c|}
\hline & Group US & Group NS & $p$ \\
\hline Age (years) & $47.6 \pm 13.6$ & $46.5 \pm 15.9$ & 0.63 \\
\hline Height (cm) & $166 \pm 8.2$ & $168 \pm 9.1$ & 0.22 \\
\hline Weight (kg) & $73.2 \pm 10.8$ & $74.3 \pm 11.6$ & 0.52 \\
\hline Gender (M/F) & $61 / 57$ & $36 / 32$ & 0.91 \\
\hline $\operatorname{ASA}(1,2,3)$ & $43 / 64 / 11$ & $28 / 35 / 5$ & 0.43 \\
\hline
\end{tabular}

\begin{tabular}{|c|c|c|c|}
\hline & Group US (n) & Group NS (n) & $\mathbf{p}$ \\
\hline Interscalen block & 54 & 30 & 0.45 \\
\hline Supraclaviculer block & 49 & 27 & 0.44 \\
\hline Infraclaviculer blok & 15 & 11 & 0.51 \\
\hline
\end{tabular}


Hematoma, pain with paresthesia, local anesthetic toxicity, respiratory distress, pneumothorax, drug allergy, and Horner's syndrome were recorded as complications (Table 4). In NS group, Horner's syndrome was seen in three patients, hematoma in three, local anesthetic toxicity in one, and pneumotorax in one patient. In US group, Horner's syndrome was seen in five patients. Patient with pneumothorax thoracic drain inserted recovered without complication, only a patient with local anaesthetic toxicity was treated with conservative therapy.

\section{Discussion}

We achieved a success rate of $94.1 \%$ in US group and $80.9 \%$ in NS group. The complication rate was lower in US group than in NS group. This study showed that US guidance was more favorable than NS guidance.

\begin{tabular}{|l|l|l|l|}
\hline \multicolumn{4}{|l|}{ Table 3. The success of the blocks } \\
\hline & Block no (n) & Succes rate (n; \%) & p \\
\hline Group USG & 118 & $111(94.1 \%)$ & \multirow{2}{*}{0.005} \\
\hline Group NS & 68 & $55(80.9 \%)$ & \\
\hline \multicolumn{4}{|l|}{ USG: Ultrasonografi, NS: Nerve stimulator } \\
\hline
\end{tabular}

\begin{tabular}{|l|l|l|}
\hline \multicolumn{4}{|l|}{ Table 4. The complications } \\
\hline & Group US (n; \%) & Group NS (n; \%) \\
\hline Hematoma & - & $3(4.4 \%)$ \\
\hline Local anaesthetic toxicity & - & $1(1.4 \%)$ \\
\hline Drug allergy & - & - \\
\hline Respiratory distress & - & - \\
\hline Pneumothorax & - & $1(1.4 \%)$ \\
\hline Horner syndrome & $5(4.2 \%)$ & $3(4.4 \%)$ \\
\hline Pain \& paresthesia & - & - \\
\hline US: Ultrasonography, NS: Nerve stimulator \\
\hline
\end{tabular}

Regional anesthetic techniques have many advantages when compared to general anaesthesia such as maintenance of patient cooperation and spontaneous breathing, controlling the airway, reducing blood transfusion needs, reducing the incidence of perioperative complications, decreasing analgesic conditions and reducing postoperative opioid consumptions $(4,11)$.

In their study, Hadzic et al. (12) compared general anaesthesia and BPB in upper extremity surgeries. They reported that BPB had an advantage over general anaesthesia for achieving good analgesic conditions, and reducing length of hospital stay and perioperative complications.

Çelik et al. (13) showed the superiority of BPB over general anesthesia in terms of operative time and hospital costs in patients undergoing upper extremity surgery. In addition, regional anaesthesia offers better pain management and minimum risk of complication.

US guidance allows for the visualization of the block needle as well as the nerves and the surrounding structures, thus reduces the complication rates compared to NS blind technique (14-16). US guidance is valuable in patients in whom NS cannot be used $(17,18)$. It is useful especially in obese patients (19).

In another study Davis et al. (20) and Martinoli et al. (21) evaluated the results of single and continuous interscalene blocks done using US guidance only and reported that US provided real time view of the needle and the brachial plexus and resulted in near full success without complications. Chan (22) stated that advanced US technology was useful for nerve localization for block technique and assessing adequacy of local anesthetic spread at the time of injection. US imaging guidance can potentially improve success during interscalene BPB. The technique used and the experience of the anaesthesiologists affect the success of block. US increases the success rate and increases the usage of regional anaesthesia (23).

Yarkan Uysal et al. (24) compared US with NS for infraclavicular block and only US without NS and found that NS did not increase the success of block, besides, the use of NS increased pain and created discomfort for the patient.

In most studies, the success rate of US-guided BPB has been reported to be $95 \%(24,25)$ and $100 \%(26)$, while, in studies comparing the US and NS techniques, the rates were $85 \%$ (27) and 90\% (28).

Also in some studies, the success rates for US and NS were as follows: in a study by Chan et al. (29), the success rate was higher in US group (82.8\%) than in NS group (62.9\%). Krutika et al. (30) reported that in US group, $96.67 \%$ of blocks achieved surgical anesthesia compared to $80 \%$ in NS group. Schwemmer et al. (31) reported a success rate of $98.2 \%$ for US and $83.1 \%$ for NS. Our results were similar with the findings of these studies. (94.1\%-80.9\%). Complications associated with BPB were hematoma, pain, local anesthetic toxicity, respiratory distress, drug allergy, pneumothorax, and Horner's syndrome $(32,33)$.

Abrahams et al. (34) compared the complications of US and NS in their reviews. They did not find any major complications such as pneumothorax, drug toxicity or nerve injuries (34). In our study, we detected Horner's syndrome in three patients $(4.4 \%)$ in NS group and five patients $(4.2 \%)$ in US group. Hematoma was observed in three patients, local anesthetic toxicity in one patient (1.4\%) and pneumothorax in one patient in NS group. There were no complications in US group. Our findings showed the 
NS was associated with much more complications than US technique. US guidance allows for the visualization of the exact place of the nerves with the surrounding structures and the needle. Also, there are studies showing that US technique decreases the local anesthetic volume and the complications such as diaphragmatic paralysis (35-37). In our study, we used $0.5 \%$ bupivacaine and $2 \%$ lidocaine as did Gürkan et al. (37) in their study.

In another study, Soeding et al. (26) and Kefalianakis and Spohner (38) performed BPB with US and they found that US guidance decreased the time to onset of the sensory and the motor block.

\section{Study Limitations}

The limitation in our study was that since it was a retrospective study, we did not evaluate the time to onset of the block. Further prospective studies evaluating the time to the onset of sensory and motor blocks with the hemodynamics parameters are needed.

\section{Conclusion}

Our study showed that the US-guided technique was superior to NS technique with less complication rates.

\section{Authorship Contributions}

Surgical and Medical Practices: C.K., H.A. Concept: C.K., H.A., Y.A., O.U. Design: A.K. Ö.FŞ. E.G. Data Collection or Processing: C.K., H.A. Analysis or Interpretation: C.K. H.A., E.T.K. Literature Search: C.K., H.A., E.G., A.K., O.U., Y.A., E.T.K., Ö.F.Ş. Writing: C.K., E.T.K.

Conflict of Interest: No conflict of interest was declared by the authors.

Financial Disclosure: The authors declared that this study received no financial support.

\section{References}

1. Breivik H, Norum HM. Regional analgesia risks and benefits. Tidsskr Nor Laegeforen 2010;130:392-97.

2. Ciftcioğlu M, Acar S, Gurkan Y, Solak M, Toker K. Ultrasound guided multiple peripheral nerve blocks in a high-risk patient. Agri 2012;24:90-2.

3. Gadsden JC, Tsai T, Iwata T, Somasundarum L, Robards C, Hadzic A. Low interscalene block provides reliable anesthesia for surgery at or about the elbow. J Clin Anesth 2009;21:98-102.

4. O'Donnell BD, lohom G. Regional anesthesia techniques for ambulatory orthopedic surgery. Curr Opin Anaesthesiol 2008;21:723-28.

5. Perlas A, Niazi A, McCartney C, Chan V, Xu D, Abbas S. The sensitivity of motor response to nerve stimulation and paresthesia for nerve localization as evaluated by ultrasound. Reg Anesth Pain Med 2006;31:445-50.

6. Tsai TP, Vuckovic I, Dilberovic F, et al. Intensity of the stimulating current may not be a reliable indicator of intraneural needle placement. Reg Anesth Pain Med 2008;33:207-10.
7. Daneli G, Fanelli A, Ghisi D, et al. Ultrasound vs nerve stimulation multiple injection technique for posterior popliteal sciatic nerve block. Anesthesia 2009;64:638-42.

8. Perlas A, Brull R, Chan VW, McCartney CJ, Nuica A, Abbas S. Ultrasound guidance improves the success of sciatic nerve blockat the popliteal fossa. Reg Anesth Pain Med 2008;33:259-65.

9. Casati A, Danelli G, Baciarello M, et al. A prospective, randomized comparison between ultrasound and nerve stimulation guidance for multiple injection axillary brachial plexus block. Anesthesiology 2007;106:992-96.

10. Sites BD, Beach ML, Spence BC, et al. Ultrasound guidanceimproves the success rate of a perivascular axillary plexus block. Acta Anaesthesiol Scand 2006;50:678-84.

11. Valentin N, Lomholt B, Jensen JS, Hejgaard N, Kreiner S. Spinal or general anaesthesia for surgery of the fractured hip? A prospective study of mortality in 578 patients. $\mathrm{Br} J$ Anaesth 1986;58:284-91.

12. Hadzic A, Arliss J, Kerimoğlu B. A comparison of infraclavicular nevre block versus general anesthesia for hand and wrist day case surgeries. Anesthesiology 2004;101:127-32.

13. Çelik F, Tüfek A, Yıldırım Z, ve ark. Üst ekstremite cerrahisinde uygulanan brakial pleksus sinir bloğu deneyimlerimiz. Dicle Tıp Dergisi 2012;39:31-4.

14. Winnie AP. Interscalene brachial plexus block. Anesth Analg 1970;49:455-66.

15. Koscielniak-Nielsen ZJ, Nielsen PR, Nielsen SL, et al. Comparison of transarterial and multiple nerve stimulation techniques for axillary block using a high dose of mepivacaine with adrenaline. Acta Anaesthesiol Scand 1999;43:398-404.

16. Gray AT. Ultrasound guided regional anesthesia: current stateof the art. Anesthesiology 2006;104:368-73.

17. Jan van Geffen G, Tielens L, Gielen M. Ultrasound guided interscalene brachial plexus block in a child with femur fibula ulna syndrome. Paediatr Anaesth 2006;16:330-2.

18. Baumgarten RK, Thompson GE. Is ultrasound necessary for routine axillary block? Reg Anesth Pain Med 2006;31:88-9.

19. Li C, McCartney C, Perlas A, Chan V. Successful use of ultrasound guided axillary block in three morbidly obese patients. Reg Anesth Pain Med 2004;29:A52.

20. Davis JJ, Swenson JD, Greis PE, Burks RT, Tashjian RZ. Interscalene block for postoperative analgesia using only ultrasound guidance: the outcome in 200 patients. J Clin Anesth 2009;21:272-7.

21. Martinoli C, Bianchi S, Santacroce E, Pugliese F, Graif M, Derchi LE. Brachial plexus sonography: a technique for assessing the root level. AJR Am J Roentgenol 2002;17:699-702.

22. Chan VW. Applying ultrasound imaging to interscalene brachial plexus block. Reg Anesth Pain Med 2003;28:340-3.

23. Koscielniak-Nielsen ZJ. Ultrasound guided peripheral nerve blocks: what are the benefits? Acta Anaesthesiol Scand 2008;52:727-37.

24. Yarkan Uysal H, Acar HV, Tezer E, ve ark. Ultrasonografi (Us) rehberliğinde infraklaviküler blok: Us ile Us + sinir 
stimülasyonunun prospektif, randomize çalışmayla karşılaştırılması. Anestezi Derg 2013;21:106-12.

25. Chan VW, Perlas A, Rawson R, Odukoya O. Ultrasound guided supraclavicular brachial plexus block. Anesth Analg 2003;97:1514-7.

26. Soeding PE, Sha S, Royse CE, Marks P, Hoy G, Royse AG. A randomized trial of ultrasound guided brachial plexus anaesthesia in upper limb surgery. Anaesth Intensive Care 2005;33:719-25.

27. Zencirci B, Öksüz H. Comparison of Nerve Stimulator and Ultrasonography Application for Brachial Plexus Anesthesia. Balkan Med J 2012;29:10-3.

28. Williams SR, Chouinard P, Arcand G, et al. Ultrasound guidance speeds execution and improves the quality of supraclavicular block. Anesth Analg 2003;97:1518-23.

29. Chan VW, Perlas A, Mc Cartney CJ, Brull R, Xu D, Abbas S Ultrasound guidance improves success rate of axillary brachial plexus block. Can J Anaesth 2007;54:176-82.

30. Krutika BR, Birva NK, Veena RS, Bina KP. Supra-Clavicular Brachial Plexus Block: Ultra-Sonography Guided Technique Offer Advantage Over Peripheral Nerve Stimulator Guided Technique. Natl J Med Res 2013;3:241-4.

31. Schwemmer U, Schleppers A, Markus C, Kredel M, Kirschner $\mathrm{S}$, Roewer N. Operative management in axillary brachial plexus blocks: comparison of ultrasound and nerve stimulation. Anaesthesist 2006;55:451-6.
32. Borgeat A, Ekatodramis G, Kalberer F, Benz C. Acute and nonacute complications associated with interscalene block and shoulder surgery: A prospectivestudy. Anesthesiology 2001;95:875-80.

33. Brown DL, Cahill DR, Bridenbaugh LD. Supraclavicular nerve block: Anatomic analysis of a method to prevent pneumothorax. Anesth Analg 1993;76:530-5.

34. Abrahams MS, Aziz MF, Fu RF, Horn JL. Ultrasoundguidance compared with electrical neurostimulation forperipheral nerve block: A systematic review and metaanalysis of randomized controlled trials. British J Anaesthesia 2009;102:408-17.

35. McNaught A, Shastri U, Carmichael N, et al. Ultrasound reduces the minimum effective local anaestheticvolume compared with peripheral nerve stimulation forinterscalene block. Br J Anaesth 2011;106:124-30.

36. Riazi S, Carmichael N, Awad I, Holtby RM, McCartney CJ. Effect oflocal anaesthetic volume (20 vs $5 \mathrm{ml}$ ) on the efficacy and respiratory consequences of ultrasound guided interscalene brachial plexus block. Br J Anaesth 2008;101:549-56.

37. Gürkan Y, Hoşten T, Tekin M, Acar S, Solak M, Toker K. Brakiyal pleksus bloğunda ultrason eşliğinde supraklavikuler ve infraklavikuler yaklaşımın karşılaştırılması. Ağrı 2012;24:15964.

38. Kefalianakis F, Spohner F. Ultrasound guided blockade of axillary plexus brachialis for hand surgery. Handchir Mikrochir Plast Chir 2005;37:344-8. 